collection of books of general interest. Wherever possible there should be a separate reading room, and in institutions doing advanced work small rooms should be provided for individual study and research. To secure full value from the library service, the library should be under the supervision of someone who has had a measure of special training and $\theta x-$ perience in library work. Alternative methods of recruitment to this end are discussed in the report. It is further recommended that properly qualified librarians employed in technical institutions should always be regarded as equal in status to members of the teaching staff and be paid on the Burnham Technical Scale-graduate or non-graduate-according to qualifications. An annual allocation for the provision of books, periodicals and binding of $3 s$. per student for the first 2,000 students and $2 s$. per student for each subsequent student is recommended.

\section{Uniformity of Mycological Terms}

The Plant Pathology Committee of the British Mycological Society has addressed a circular letter to organizations in the British Isles which use the scientific names of fungi causing plant diseases. It is suggested that an agreement to use the names from a standard list of plant pathogens would be of great convenience, and would strengthen attempts to secure international uniformity. The proposed standard names are those included in the "List of Common Names of British Plant Diseases" (published for the Plant Pathology Committee of the British Mycological Society by the Cambridge University Press, 1934). Mycological nomenclature is greatly in need of any authoritative lead such as the one now proposed. It would, in fact, be very gratifying if the present modest suggestions should not only find immediate acceptance, but would also be extended later. A universally acceptable standard of naming for all fungi is urgently needed. The British Mycological Society has, moreover, always maintained a proper balance between all the branches of its study. It should, therefore, be accorded the full support of all mycologists of Great Britain. The Society has accepted its Committee's suggestions on nomenclature for all papers on pathogenic fungi, which will be published in its volumes of Transactions. Provision has been made for any desirable criticisms to be advanced against the actual list of names, and it is proposed to issue periodical revisions. Further particulars of the scheme may be obtained from the Secretary of the Plant Pathology Committee, Dr. G. C. Ainsworth, Experimental and Research Station, Cheshunt, Herts.

\section{Horticulture of the Amaryllidaceæ}

"Herbertia", the fifth year-book of the American Amaryllis Society (From the Editor, Mira Flores, Orlando, Florida, U.S.A., 1938) maintains a proper balance between needs of the grower, the scientific worker and the teacher, and attains a human interest in addition. The present volume is dedicated to Ernst H. Krelage (Holland), about whom an interesting autobiography appears. Classification of the Amaryllidace is somewhat difficult, but a series of papers by Dr. H. P. Traub and J. C. Th. Uphof clarifies some obscurities and makes possible a tentative revision of the genus Amaryllis. Cytological studies have also been used by Walter $S$. Flory to re-establish the genus Habranthus. Experiments by W. M. James upon vernalizing seed of Leucocoryne Ixioides indicate the possibility of much faster production of flowering-size plants. I. W. Heaton reviews the possibilities of growing hybrid amaryllids with culture solutions instead of compost, and preliminary experiments suggest a useful and extremely economic method of culture. The section on harvesting, storage and forcing contains two mutually complementary papers by Dr. John Grainger (England), who describes the scientific principles underlying the production of early bloom, and by Prof. E. van Slogteren (Holland), who considers the practices for early forcing. "Herbertia" has also the usual descriptions of regional activities and garden culture. It is comprehensive, and succinct yet adequate. The policy of Dr. Hamilton P. Traub, its editor, presents the requisite blend of new and established knowledge which is essential for progress in modern horticulture.

\section{A Doctors' Peace Manifesto}

The Balkan Medical Union (Athens, Belgrade, Bucarest and Istanbul) has addressed an appeal to medical men of all nations to take active measures to awaken public opinion on the horrors of war, and the terrible sufferings it inflicts upon the civil population of open towns. The Union believes that "only enlightened international opinion can make plain the imminence of the danger, and the uselessness, even for the victor, of war-time atrocities. The immutable truth that hate breeds only hate, and atrocity breeds vengeance, must be impressed on everyone". The Balkan Medical Union, founded in 1931, is essentially: a scientific organization; but it also aims at bringing together the intellectuals of different countries so that they may know one another, and come to a mutual respect and understanding, whereby the misunderstandings that engender hate and disastrous struggles between nations may be dispelled.

\section{The League of Nations}

A Revisen edition of the "Aims, Methods and Activities of the League of Nations", which first appeared in 1935, has now been published (Geneva : League of Nations; London: George Allen and Unwin, Ltd., 1938. 2s.). Like the first edition it consists of four parts, the first including a historical account of international organization followed by a description of the nature, aims and methods of the League. The second part attempts to describe and assess impartially the achievements of the League, and although eminently readable and not overburdened with detail, gives a good comprehensive account of its work, which at the same time indicates some of the causes of its success and failure. The chief criticism that can be advanced of this section, 